\section{Explosive New Zealand mistletoe}

SIR - Many flowers of the mistletoe Peraxilla tetrapetala (Loranthaceae) in New Zealand open from the bottom ( $f$ in the figure) rather than the top $(d)$; Kuijt ${ }^{1}$ called this an "unsolved mystery ... we cannot even guess at the meaning of this bizarre performance." Here we report that flower buds of $P$. tetrapetala and $P$. colensoi open from the top only when twisted by a bird, a form of 'explosive' flower opening common in Africa but previously unknown in Australasia. Kuijt's "bizarre performance" is simply the consequence of flowers not being visited by birds. However, pollination in Peraxilla is possible without birds: unvisited flowers sometimes self-pollinate when the petals undergo abscission from the bottom.

The closely related Alepis flavida may show how explosive opening evolved. Its flowers open unaided, but birds twist buds to try and open them early. Another close relative, Trilepidea adamsii, is believed extinct, but historical paintings and herb-

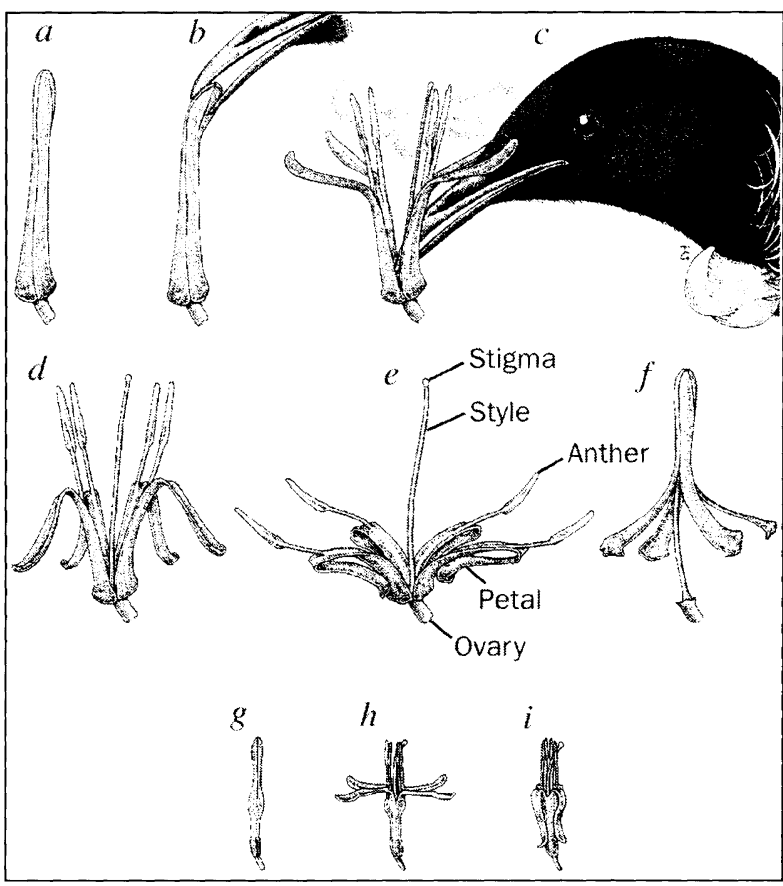

Explosive flower opening in the New Zealand mistletoe Peraxilla colensoi (a-f) and its possible precursor in Alepis flavida ( $g-i$ ). $P$. colensoi: $a$, Unopened bud, mean length $47 \mathrm{~mm}$. $b$, Bird (a tui) grasps the top of a ripe bud with its beak and twists. $c$, After $0.55 \pm 0.10 \mathrm{~s}$ (mean $\pm 95 \%$ confidence interval, from 23 video recordings), the flower explodes open, flinging pollen from the already-dehisced anthers, and the bird drinks nectar from the side or above, pollinating the flower. $d$, Four hours after opening, petals have folded back further. Birds ignore open flowers, which produce little nectar after the ripe-bud stage. $e$, Three days after opening, petals fold back through $180^{\circ}$. $f$, Without a twist from a bird, the top of the flower never opens, but 4-8 days after bud ripening the petals undergo abscission from the base and pull the anthers over the top of the stigma, aiding self-pollination. Alepis flavida: this species does not have explosive flowers, and flowers open unaided. However, impatient birds sometimes twist flowers to try and open them early. g, Unopened bud, mean length 20 $\mathrm{mm}$. $h$, Open flower on day of opening. $i$, Petals fold back within 2 days of opening. Drawings by T. Galloway. pattern, as do herbarium sheets (for example, 4 of 7 flowers on sheet AK103910). Trilepidea almost certainly had more complex explosive flowers than Peraxilla. Such specialization may have rendered Trilepidea more sensitive to reduced bird densities due to introduced mammalian predators, contributing to its rapid and puzzling 5 decline.

Explosive flower opening is well known in other mistletoes ${ }^{6}$, including many of the 230 species in Africa ${ }^{3}$, and a few species in India ${ }^{7}$, Java, New Guinea and South America ${ }^{1,6}$. However, this is the first report from Australasia. The New Zealand flora generally displays few specialized pollination mechanisms ${ }^{8}$. We have shown that the two endemic Peraxilla mistletoes, and probably also Trilepidea, show very specialized ornithophilous pollination. This has interesting biogeographical implications, as the New Zealand Loranthaceae are generally considered primitive ${ }^{9}$.

Our study also has implications for conservation. First, if outbreeding benefits Peraxilla, bird populations must be maintained, or cross-pollination becomes impossible. Current bird populations are insufficient in some areas to open more than a minority of Peraxilla flowers. Second, learning by the birds may be important. In the North Island, Peraxilla populations have been reduced markedly by Australian brushtail possums (Trichosurus vulpecula $)^{10}$. In 1993-94, banding of trees to exclude possums allowed more extensive flowering, but the flowers were largely ignored by bellbirds (S. Dopson, personal communication), which may no longer know how to open them. Finally, posthumous recognition of explosive flowers in Trilepidea both sheds light on its extinction and increases our sadness at the fact.

\section{Jenny J. Ladley}

Dave Kelly

Plant and Microbial Sciences,

University of Canterbury,

Christchurch 1, New Zealand

1. Kuijt, J. The Biology of Parasitic Flowering Plants (Univ.

California Press, Los Angeles, 1969).
2. Gill, F. B. \& Wolf, L. L. Am. Nat. 109, 491-510 (1975).

2. Gill, F. B. \& Wolf, L. L. Am. Nat. 109, 491-510 (1975).
3. Polhill, R. M. in Tropical Forests (eds Holm-Nielsen, L. B. et al.) 221-236 (Academic, London, 1989).

4. Goulding, J. H. Fanny Osborne's Flower Paintings (Heinemann, Auckland, 1983).

5. Norton, D. A. Conserv. Biol, 5(1), 52-57 (1991).

6. Docters van Leeuwen, W. M. Beaufortia 4(41), 105-205 (1954).

. Davidar, P. Biotropica 15(1), 32-37 (1983)

8. Webb, C. J. \& Kelly, D. Trends Ecol. Evol. 8(12), 442-447 (1993)

9. Barlow, B. A. in The Biology of Mistletoes (eds Calder, M. \& Bernhardt, P.) 19-46 (Academic, Sydney, 1983).

10. Ogle, C. C. \& Wilson, P. R. Forest Bird 16 (3), 10-13 (1985).

\section{Scientific Correspondence}

Scientific Correspondence is intended to provide a forum in which readers may raise points of a scientific character. Priority is given to letters of fewer than 500 words. 